\title{
An overview of the land subsidence phenomena occurring in Greece, triggered by the overexploitation of the aquifers for irrigation and mining purposes
}

\author{
Constantinos Loupasakis \\ School of Mining and Metallurgical Engineering, National Technical University of Athens, \\ 15780 Athens, Greece
}

Correspondence: Constantinos Loupasakis (cloupasakis@metal.ntua.gr)

Published: 22 April 2020

\begin{abstract}
Land subsidence caused by overexploitation of aquifers manifests with an increasing frequency in several regions of Greece. The first signs of land subsidence have been identified since 1965 at the west side of Thessaloniki (broader Kalochori village region), in the form of a progressive marine invasion. Since then several areas have been investigated and proved to be affected mainly by the overexploitation of the aquifers. The Multidisciplinary nature of the subsidence mechanism combining the geological, hydrogeological and morphological setting of the areas with the human activities and the land use data makes their study complicated and require the intervention of multiple scientific specialties. Furthermore, at several sites, beside ground truth data, the land subsidence trends and extends have been also identified via multi-temporal InSAR techniques, such as PSI and SBAS techniques. Among the sites to be presented in the current paper is the wider area of Kalochori village in the eastern part of Thessaloniki plain, the east and west Thessaly plain in central Greece and the region extending to the west-southwest of the Amyntaio opencast coalmine in West Macedonia.
\end{abstract}

\section{Introduction}

Several sites in Greece are affected by the manifestation of land subsidence phenomena triggered by various mechanisms. For example the oxidation of organic soils triggers land subsidence at the Xiniada plain, Central Greece as well as at the Filippoi shoal extending at East Macedonia and Thrace prefectures. The natural compaction of underconsolidated soil formations triggers deformations at the Gianitsa plain, extending at the West of Thessaloniki. The collapse of old mining tunnels threatens a wide area of the Anthoupoli municipality at the city of Athens and the collapse of karstic cavities is responsible for the occurrence of several sinkholes at the Ionian Islands and in several other areas in Greece.

Among the land subsidence mechanisms, the one affecting the most extended areas and is clearly triggered by human activities is the one related to the overexploitation of the aquifers. Unlikely most of the large plain areas of Greece are affected by those phenomena. As presented in the loca- tion map of Fig. 1, the major plain areas affected are: (1) the wider Kalochori - Sindos plain area at the west of Thessaloniki, (2) the Anthemountas basin at the east of Thesaloniki, (3) The Amyntaio basin hosting the homonymous open pit coal mine, Florina prefecture, $(4,5)$ the West and East Thessaly plain, central Greece and (6) the Messara basin, Crete Island. Beside them, there are several other smaller plain areas filled with normally consolidated or even slightly overconsolidated soil formations effected by over-pumping.

An intriguing output of the studies conducted at the above mentioned sites is the uplift - rebound motion trend identified at the Kalochori site after the recovery of the aquifers. The aquifers recovered after the pause of the industrial activities due to the financial crisis in Greece.

The extensive depression cone at the perimeter of the Anargiroi opencast coalmine and its relation with the manifestation of intensive land subsidence phenomena, damaging at list two densely populated villages, is also an intriguing case study. 


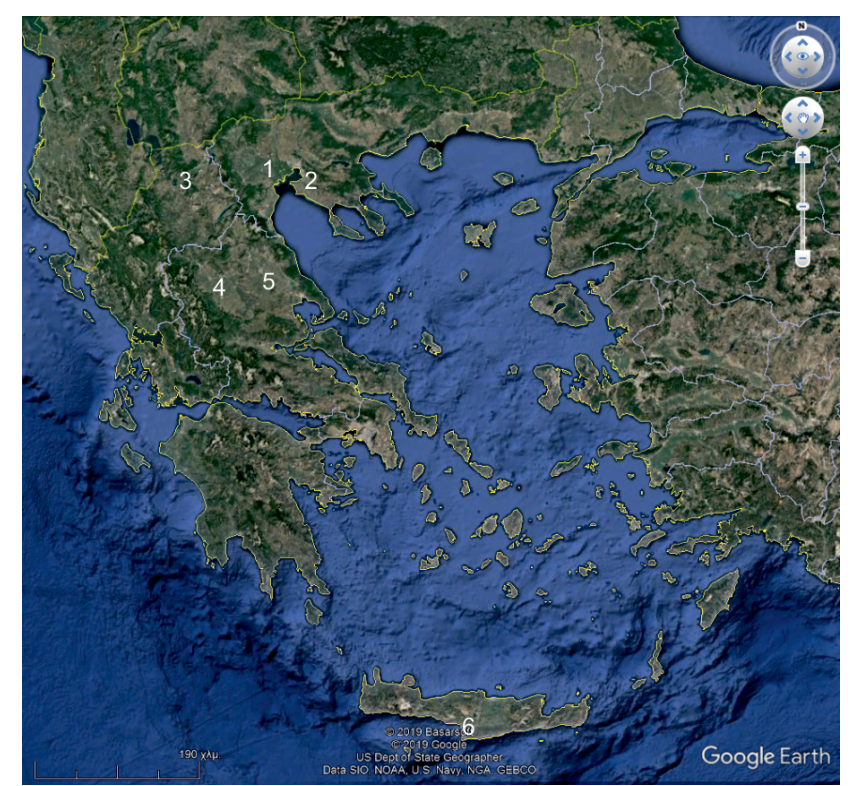

Figure 1. Location map of the major plain areas affected by the overexploitation of the aquifers. (1) Wider Kalochori - Sindos plain area, (2) Anthemountas basin, (3) Amyntaio basin, (4, 5) West and East Thessaly plain and (6) Messara basin. Base map from (C) Google Earth.

Aiming to provide an overview of the land subsidence phenomena occurring in Greece due to the overexploitation of the aquifers, the most characteristic case studies and the most intriguing results will be briefly presented at the current paper.

\section{Characteristic case studies}

\subsection{Wider Kalochori-Sindos plain area at the west of Thessaloniki}

Land subsidence in the broader Kalochori-Sindos region has been recorded since 1964 in the form of seawater invasion (Stiros, 2001; Loupasakis and Rozos, 2009). In 1965 an intensive rainfall took place, causing seawater inundation to threaten the houses of Kalochori. As a countermeasure, in 1969 the government built the first embankment to protect the area from the sea. Now, the maximum land subsidence values can be identified along the embankments where clearly the sea level is over the inland surface for more than 3 to $4 \mathrm{~m}$ (Fig. 2).

The wider area is founded over Quaternary deposits (Rozos and Hatzinakos, 1993) and despite the intensity of the land subsidence phenomena no differential displacements or surface ruptures have been reported. This phenomenon is unique, at least in Greece, and it can only be attributed to the absence of faults intersecting the top layers and the bedrock within the narrow limits of the study area. It is a fact that the faults' offset creates intensive variations at the thickness of

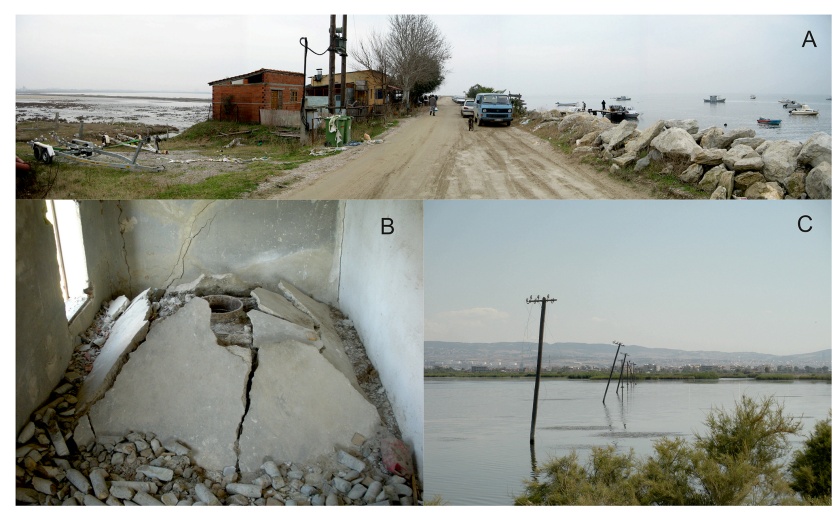

Figure 2. Field evidences of subsidence: (a) top view of the embankment proving that the sea level (right) is higher than the inland surface (left); (b) pipe's extraction in a deep well North of Kalochori and (c) submerged electricity network SW of Kalochori.

the compressible formations leading to the manifestation of differential displacements in case of ground water drawdown (Loupasakis et al., 2014).

Persistent Scatterer Interferometry (PSI) (Ferretti et al., 2000, 2001) and Small Baseline Subset (SBAS) multitemporal Interferometric approach (Berardino et al., 2002) have been applied for the analysis of 20 years ERS $1 / 2$ and ENVISAT datasets. The velocities estimated for the ERS datasets present subsidence, for the narrow area of Kalochori, with magnitude up to $35 \mathrm{~mm} \mathrm{yr}^{-1}$ (Raspini et al., 2014), fitting perfectly with the ground-truth data. Also, according to the interferometric data the phenomena extend to the north affecting Sindos. At this point it should be noted that the fact that the phenomena also affect Sindos was first recognised after the evaluation of the first Interferometric data. The uniform subsidence of the site and its great distance from the coastline did not provided any indications to suspect the occurrence of such phenomena so far north in the mainland.

Nevertheless, the intriguing output was provided by the ENVISAT data archive covering the period 2003-2010, showing that there was a change in motion trend, from subsidence to uplift (Fig. 3) (Svigkas et al., 2016). The uplifting trend of the second decade is well correlated with hydrogeological data following a synchronous rise of the aquifer water level, but with an offset of 1.5 years. Furthermore, by examining the graph of Fig. 4, it is clear that the synchronization is so perfect that since 2007 the uplifting signal becomes smoother, following the smoother recovery of the aquifers.

\subsection{East and west Thessaly plain in central Greece}

The Thessaly plain, located in central Greece, is a large plain further divided, by hills, into two parts the East and the west plain. At the east Thessaly plain, the land subsidence phenomena have been observed since 1986 when numerous ground raptures appeared causing extensive damages to lin- 


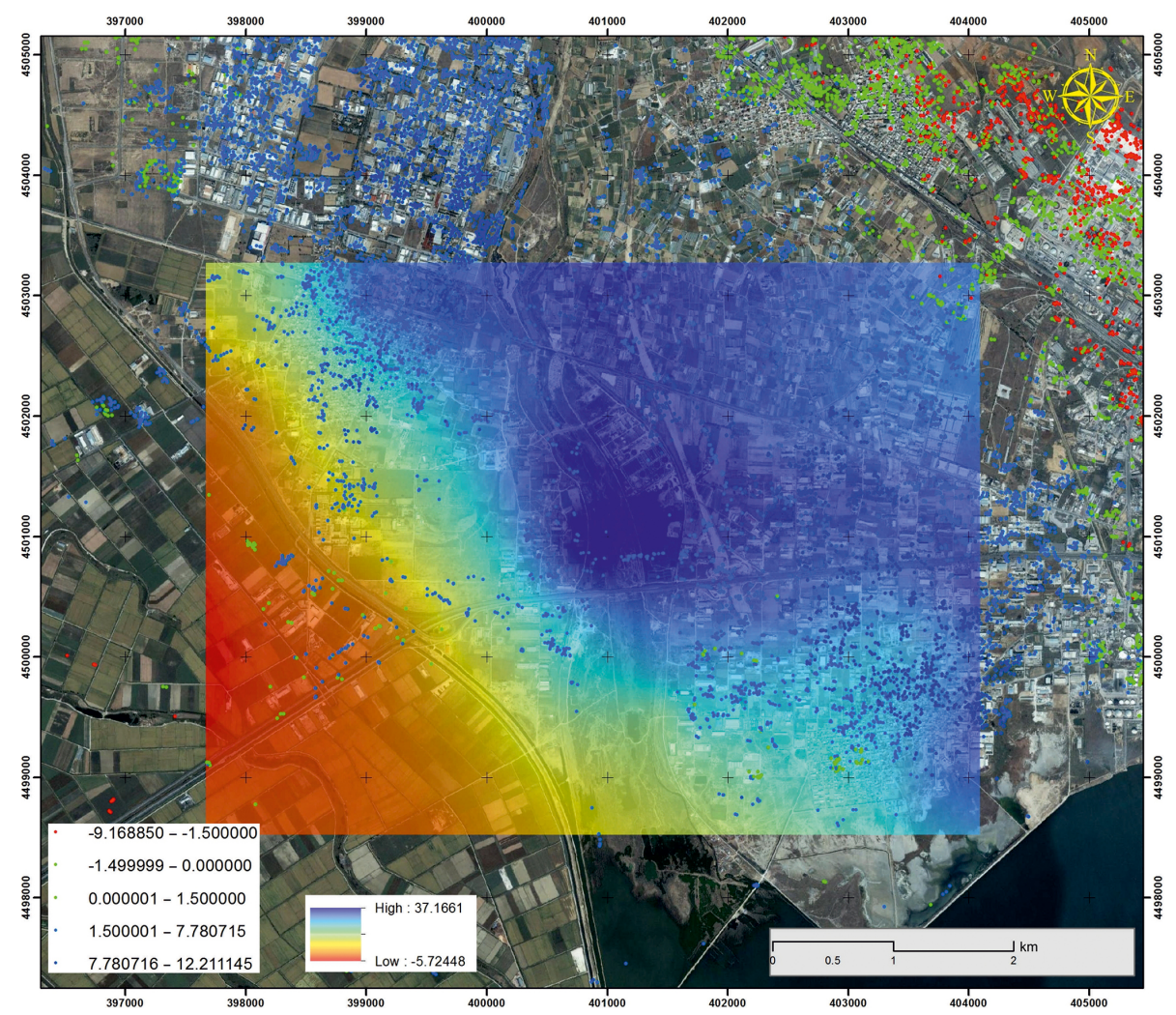

Figure 3. The groundwater recharge (contour shading in $\mathrm{m}$ ) between June 2000 and June 2015 correlated with the displacements along LOS in $\mathrm{mm} \mathrm{yr}^{-1}$ from 2003 to 2010 (SAR data - dots). The aquifers recharge triggers the uplift of the study area (Svigkas et al., 2016).

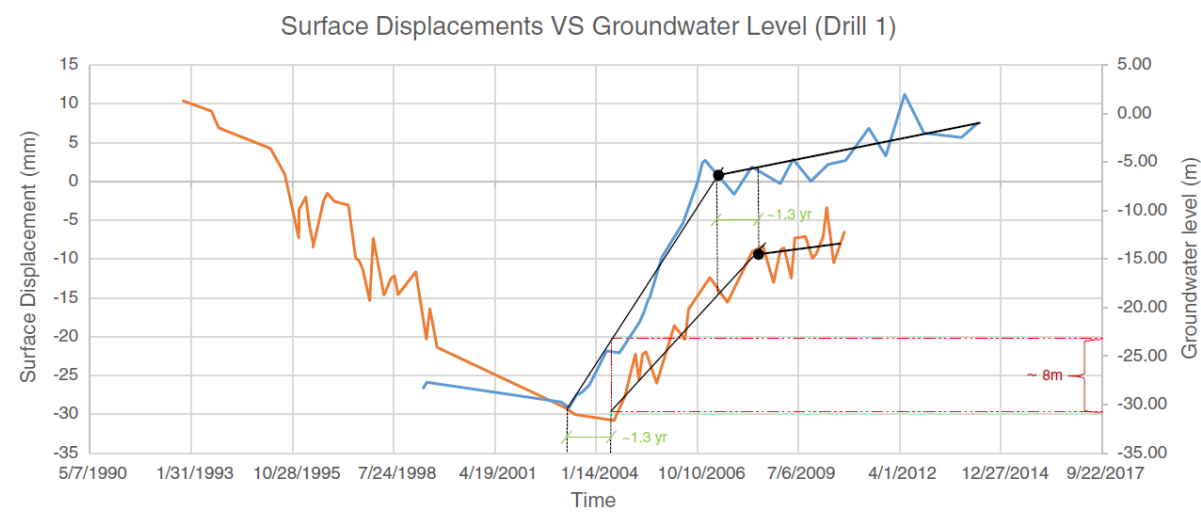

- Surface Displacements —Groundwater leve

Figure 4. Graph comparing the ground water level variations at Drills 1 with the surface deformation time series at nearby data points produced by the SAR analysis (Svigkas et al., 2016).

ear infrastructure and settlements (Fig. 5). The fact that the surface raptures are parallel to the Quaternary faults crossing the plain led some scientists to correlate the differential deformations with a so called "aseismic tectonic creep" along the faults (Kontogianni et al., 2007). A careful study of the kinematics of the ground fissures, and a correlation of the deformations with the ground water depression piezometric surface revealed that they are related to the over-pumping of the aquifers. As indicated by piezometric level measurements, since the early 80's (1982-1983), the aquifer systems of the study area have been subject to excessive overexploitation.

At the west Thessaly plain, the land subsidence phenomena have been intensified since 2002. In the Quaternary deposits of the plain, constituting of Pleistocene sand and gravel horizons with brown and grey clayey silt to 


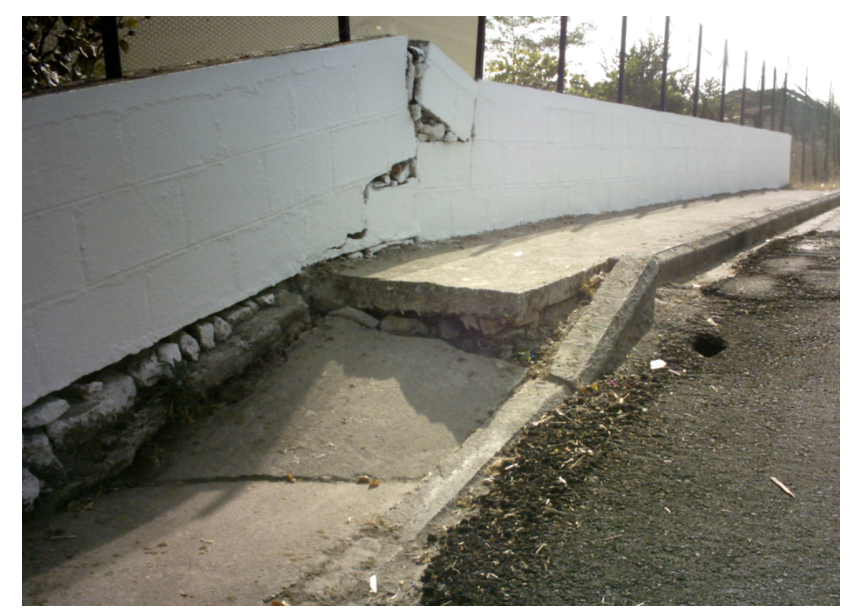

Figure 5. Intensive surface deformations occurring at the Niki Village, at the East Thessaly Plain.

silty clay intercalations, highly productive aquifers are developed. These alternations of permeable coarse-grained deposits (aquifers) with impermeable to low permeability strata (aquitards) create shallow unconfined aquifers and a number of successive semi-confined to confined aquifers, sometimes artesian (Ilia et al., 2018). A great number of wells exploit the unconfined aquifers for irrigation purposes triggering the land subsidence phenomena. Concerning the reported damages due to land subsidence, the majority of them have affected roads and private buildings in the town of Farsala and the villages of Agios Georgios, Stavros and Anochori. Similar to the East Thessaly plain, the surface raptures are parallel to the Quaternary faults crossing the plain. Figure 6 presents the spatial distribution of the surface raptures following the tectonic lines as well as the distribution of the deformations at the town of Farasla. It is clear that the deformations affect only parts of the town that are founded on the Quaternary formations, while the parts located over the limestone of the bedrock remain, as expected, stable.

\subsection{The perimeter of the Anargiroi opencast coalmine, Florina Prefecture, West Macedonia}

The land subsidence phenomena caused by the dewatering of the mines are listed among the mining-induced catastrophic geohazards slowly affecting extensive areas around the opencasts, causing irreversible damages.

The site under investigation is the area extending westnorthwest of the Amyntaio opencast coal mine, located at the homonymous basin at Florina Prefecture. This mine will be active for several more years, and currently a second mine (Filotas mine) is excavated within the limits of the basin, as a replacement source of coal.

According to recent measurements, the ground water-table drawdown close to the mine is more than $70 \mathrm{~m}$ (Tzampoglou and Loupasakis, 2017, 2018). Actually; the overall excava- tion including the surrounding draining wells acts as an infinitely operating deep well with a diameter of approximately $4 \mathrm{~km}$, draining most of the basin. At this point, it should be noted that besides the mining activities, the overexploitation of the aquifers in the wider basin is also amplified by an increasing number of farmers' irrigation wells. But from the form of the overall depression cone is clear that the dominant braining activity is the mining. The overexploitation of the aquifers has triggered, since 2005, extensive land subsidence phenomena. These phenomena extend $2-3 \mathrm{~km}$ around the mine causing damages to three villages so far: Anargiroi, Valtonera and secondarily Fanos. The surface raptures were initially reported at 2001 in the urban area of the Anargiri village and by 2006 the damages affected the entire plain; including the distant village of Fanos, located $4 \mathrm{~km}$ away from the mine.

The orientation of the surface raptures is clearly related to the orientation of the main tectonic lines forming the plain (Fig. 7). The differential vertical displacements across the fractures are inversely proportional to the distance from the mine. The maximum values are recorded right next to the mine's crest, reaching up to offset values of $0.5-1 \mathrm{~m}$, while the fractures gradually faint moving away from the mine (Loupasakis et al., 2014).

At the Valtonera village, a single fracture intersects the entire village causing differential vertical displacements up to $30 \mathrm{~cm}$ (Fig. 8). On the contrary, at the Anargiri village, which is much closer to the mine, the deformations distribution is more complicated. Multiple fractures' directions are recorded following both the tectonic lines directions as well as the ground water depression cone contour lines.

A farther investigation of the phenomenon was conducted by applying numerical simulations (Loupasakis et al., 2014; Tzampoglou and Loupasakis, 2018). The simulations were aiming to the study of the phenomenon at the most heavily damaged area of the villages and to the parametric simulation of the influence of the geological profile's geometry on the surface deformations.

The parametric simulations proved that the faults' offset is the main parameter affecting the differential displacements of the surface and the occurrence of the surface raptures. Also, the common result of the simulations was that the ground water drawdown affects intensively the surface raptures offset. So as verified by the ground truth data the simulations also proved that the vertical displacements decrease moving away from the crest of the mine.

\section{Discussion}

Land Subsidence triggered by the overexploitation of the aquifers is a quiet natural hazard, evolving very slowly, and sometimes taking place for decades before it gets noticed. As an example, the deformations at the narrow area of Sindos, 


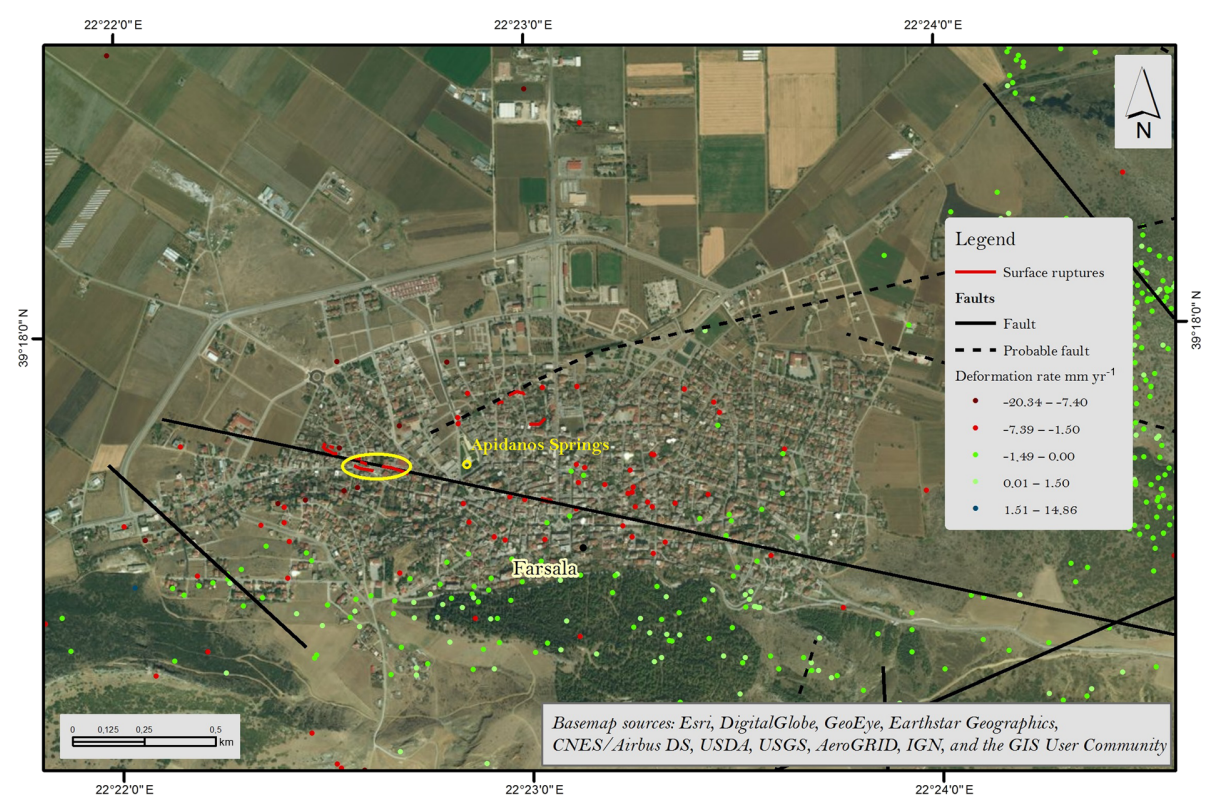

Figure 6. The spatial distribution of the surface raptures and PSI data (modified from Ilia et al., 2018).

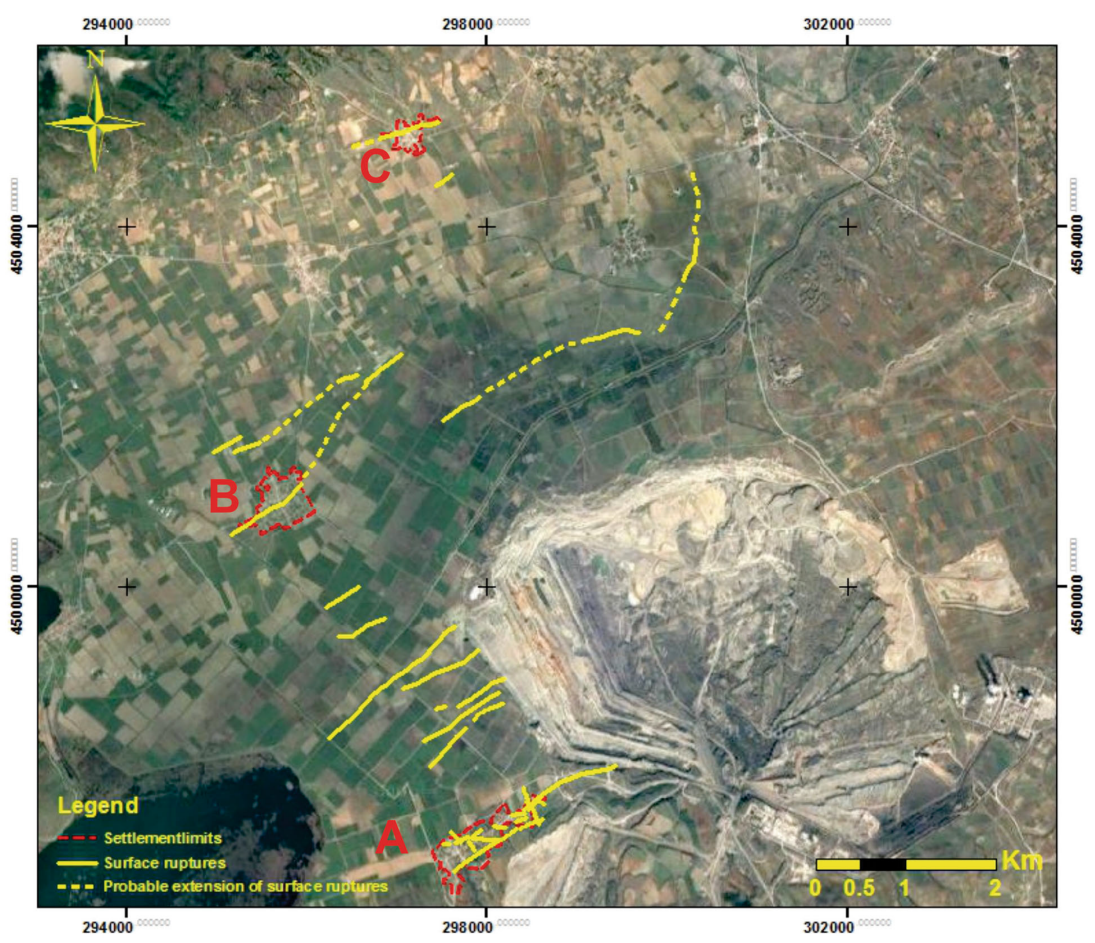

Figure 7. Intensive Distribution of the surface ruptures at the Amyntaio basin. A. Anargiroi, B. Valtonera and C. Fanos villages (Tzampoglou and Loupasakis, 2017).

due to the lack of deferential deformations, were first realised around 2010, more than 50 years after they were triggered.

Reviewing all above case studies, it is clear that besides the ground water drawdown, the factor affecting the most the occurrence of differential deformations is the existence of tectonic faults at the base rock formations of the plain.
The alterations on the thickness of the compressible soil layers, imposed by the faults' offset, allows the manifestation of differential displacements along the projection of the fault on the surface of the plain.

At all above described case studies, differential deformations, and as a result surface raptures, were recorded only at 


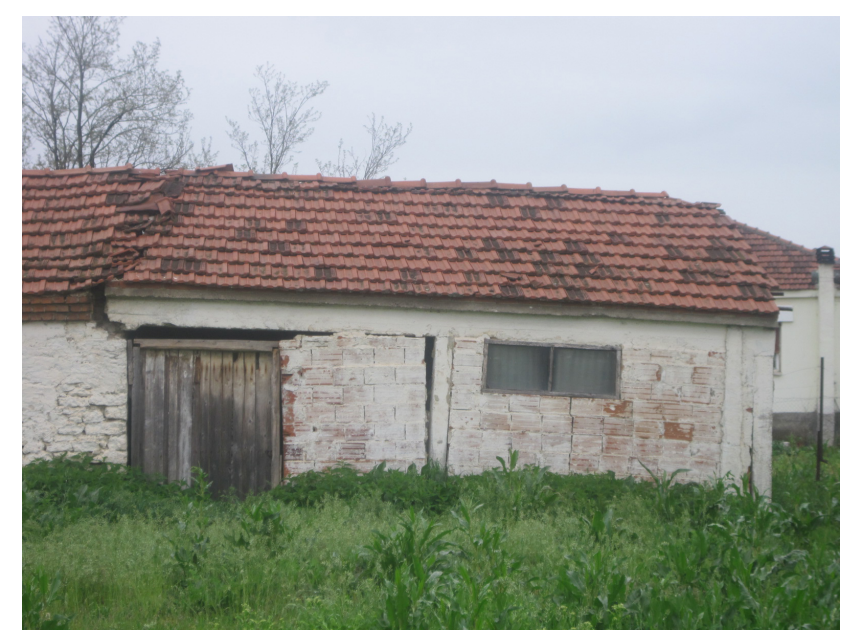

Figure 8. Building damaged by the surface deformations occurring at the Valtonera Village, at the West of the Amyntaio Open Pit Coal Mine, West Macedonia.

the plain areas where the base rock formations were intersected by tectonic lines.

To the direction of the mining risk management, is clear that the intensity as well as the extent of the land subsidence can be predicted using hydrogeological and geotechnical studies to determine mechanisms of the phenomena by combining ground truth data and modeling procedures. So, mining project managers can make proper decisions to protect natural and urban environments by reducing impacts of the mining hazard.

An also interesting conclusion is that due to the grate extend of the phenomena and their low deformation rates the Interferometric techniques has be proved to be a valuable tool for their study.

Data availability. No data sets were used in this article as this is a review article.

Competing interests. The authors declare that they have no conflict of interest.

Special issue statement. This article is part of the special issue "TISOLS: the Tenth International Symposium On Land Subsidence - living with subsidence". It is a result of the Tenth International Symposium on Land Subsidence, Delft, the Netherlands, 17-21 May 2021.

Acknowledgements. I acknowledge all researchers participated to the numerous studies cited in this review article.

\section{References}

Berardino, P., Fornaro, G., Lanari, R., and Sansosti, E.: A new algorithm for surface deformation monitoring based on small baseline differential SAR interferograms, IEEE T. Geosci. Remote, 40, 2375-2383, 2002.

Ferretti, A., Prati, C., and Rocca, F.: Nonlinear subsidence rate estimation using permanent scatterers in differential SAR interferometry, IEEE T. Geosci. Remote, 38, 2202-2212, 2000.

Ferretti, A., Prati, C., and Rocca, F.: Permanent scatterers in SAR interferometry, IEEE T. Geosci. Remote, 39, 8-20, 2001.

Ilia, I., Loupasakis, C., and Tsangaratos, P.: Land subsidence phenomena investigated by spatiotemporal analysis of groundwater resources, remote sensing techniques and random forest method: the case of Western Thessaly, Greece, Environ. Monit. Assess., 190, 623, https://doi.org/10.1007/s10661-018-6992-9, 2018.

Kontogianni, V., Pytharoulis, S., and Stiros, S.: Ground subsidence, Quaternary faults and vulnerability of utilities and transportation networks in Thessaly, Greece, Environ. Geol., 52, 1085-1095, 2007.

Loupasakis, C. and Rozos, D.: Land subsidence induced by water pumping in Kalo-chori village (North Greece) - simulation of the phenomenon by means of thefinite element method, Q. J. Eng. Geol. Hydroge., 42, 369-382, 2009.

Loupasakis, C., Angelitsa, V., Rozos, D., and Spanou, N.: Mining geohazards - land subsidence caused by the dewatering of opencast coal mines: the case study of the Amyntaio coal mine, Florina, Greece, Nat. Hazards, 70, 675-691, 2014.

Raspini, F., Loupasakis, C., Rozos, D., Adam, N., and Moretti, S.: Ground subsidence phenomena in the Delta municipality region (Northern Greece): Geotechnical modeling and validation with Persistent Scatterer Interferometry, Int. J. Appl. Earth Obs. Geoinf., 28, 78-89, 2014.

Rozos, D. and Hatzinakos, I.: Geological conditions and geomechanical behaviour ofthe neogene sediments in the area west of Thessaloniki (Greece), Proceedingsof International Symposium on Geotechnical Engineering of Hard Soils-SoftRocks, Balkema, Greece, 1993.

Stiros, S. C.: Subsidence of the Thessaloniki (northern Greece) coastal plain, 1960-1999, Eng. Geol., 61, 243-256, 2001.

Svigkas, N., Papoutsis, I., Loupasakis, C., Tsangaratos, P., Kiratzi, A., and Kontoes, Ch.: Land subsidence rebound detected viamulti-temporal InSAR and ground truth data in Kalochori and Sindos regions, Northern Greece, Eng. Geol., 209, 175-186, https://doi.org/10.1016/j.enggeo.2016.05.017, 2016.

Tzampoglou, P. and Loupasakis, C.: Mining geohazards susceptibility and risk mapping: The case of the Amyntaio open-pit coal mine, West Macedonia, Greece, Environ. Earth Sci., 76, 542, https://doi.org/10.1007/s12665-017-6866-4, 2017.

Tzampoglou, P. and Loupasakis, C.: Evaluating geological and geotechnical data for the study of land subsidence phenomena at the perimeter of the Amyntaio coalmine, Greece, Int. J. Min. Sci. Technol., 28, 601-612, https://doi.org/10.1016/j.ijmst.2017.11.002, 2018. 